\title{
ENLIGHTENING ISLAMIC PREACHING: Study on $D a$ 'wah of Muhammadiyah in The Contemporary Era
}

\author{
ICHWANSYAH TAMPUBOLON \\ Lecturer of Da'wah and Communication Science Faculty, IAIN Padangsidimpuan \\ Jl. T. Rizal Nurdin Km. 4.5 Sihitang Padangsidimpuan 22733 \\ Email: ichwansyah.tampubolon@yahoo.com
}

\begin{abstract}
Abstrak
Dakwah Pencerahan merupakan sebuah model dakwah baru ala Muhammadiyah di zaman kekinian. Secara konseptual, di satu sisi, Dakwah Pencerahan dapat difahami sebagai sebuah pemikiran di bidang dakwah secara kreatif dan innovatif. Ia berupaya mengintegrasikan secara interkonektif sejumlah dimensi prinsip-prinsip Islam dengan kearifan lokal dan nilai-nilai kemanusiaan universal dalam upaya merekonstruksi sebuah fomulasi baru di bidang dakwah. Di sisi lain, ia juga dapat dipandang sebagai sebuah gerakan dakwah yang progressif dan signifikan oleh karena upayanya untuk menemukan solusi secara realistik dan cerdas atas persoalan-persoalan masyarakat Muslim dan kemanusiaan, terutama dalam konteks memajukan masyarakat Indonesia.

Kata Kunci: Muhammadiyah, Model Dakwah, Dakwah Pencerahan, Islam Berkemajuan
\end{abstract}

\begin{abstract}
The Enlightening Islamic preaching is a new model of da'wah of Muhammadiyah in the contemporary era. Conceptually, in the one side, the Enlightening Islamic preaching can be comprehended as a creative and innovative thought of da wah. It efforts to integrate interconnectively some dimensions of Islamic principles with Indonesian local wisdoms and universal humanity values in order to reconstruct a new formulation of da wah. And, in the other side, it's also can be seemed as a very progressive and significant movement of $d a^{\text {`wah }}$ because it attempts to find the real and smart solutions to some problems of Islamic societies and humanities, especially in the context of modernization of Indonesian peoples.

Keywords: Muhammadiyah, Model of Da'wah, Enlightening Islamic Preaching, Progressive Islam
\end{abstract}




\section{INTRODUCTION}

Until one half decade of the first twenty century, there have been some paradigms of da'wah movements in Islamic world, such as: traditionalism (example: Nahdatul Ulama, al-Washliyah, al-Ittihadiyah, i.e.), neo-modernism, liberalism, revivalism; neo-revivalism, radicalism, fundamentalism, militanism and transnationalism, such as: Salafiah, Hizb al-Tahrîr, Majlis Mujâhidîn, Tarbiyyah, Jamâ'ah Tablîgh, Ikhwân al-Muslimîn (Egypt), Jama'at Islami (Pakistan) and Taliban (Afghanistan). Uniquely, none of these paradigms of da'wah was adopted by Muhammadiyah, but, it has had the different style of da 'wah movement in the contemporary era as called Dakwah Pencerahan (The enlightening Islamic preaching or al-Da'wah al-Tanwîriyyah in Arabic). This slogan which is proclaimed at the beginning of the second centuries of its life can be comprehended not only as an attempt to reconceptualize and to revitalize it's existence, but also as a legitimation of it's characteristic, if not it's excellence, in the field of da 'wah from the others in contemporary Islamic world. ${ }^{1}$

\section{DESCRIPTION}

\section{The Defenition of The Enlightening Islamic Preaching of Muhammadiyah}

On Muhammadiyah's perspective, at least, there are four defenitions of da'wah. First, da'wah is a process of islamization of some aspects of human life into the divine paths or Islamic teachings. Second, da'wah is a process of actualization of prophetic duties and roles. Third, $d a^{\prime} w a h$ is a process of invitation of Islamic doctrines to all of the world. Fourth, da'wah is a process of operationalization of Islamic teachings as gifts from God to all creatures in order to creat the prosperious life of ummah, bring happiness and give solutions to the problems of human being. ${ }^{2}$

Since it's establishment in 1912 until now, da'wah of Muhammadiyah has not only been still holding on firmly to it's commitment enjoing what is right and forbidding what is wrong verbally, but also actualizing empirically the revealed Islamic teachings as divine gifts or guidance from The One God to all

${ }^{1}$ PP Muhammadiyah, Pernyataan Pikiran Muhammadiyah Abad Kedua, Zhawâhir al-Afkâr alMuhammadiyah li al-Qarni al-Tsâni, Keputusan Muktamar Satu Abad Muhammadiyah (Muktamar ke-46 di Yogyakarta), (Yogyakarta dan Jakarta: PP Muhammadiayah, 2015), p. 14

${ }^{2}$ Haedar Nashir, "Dakwah Muhammadiyah dalam Perspektif Sosiologis", Makalah. Disampaikan pada Seminar Pra-Muktamar Satu Abad Muhammadiyah Tanggal 18-19 Desember 2009, di Kampus UMSU, Medan, p. 4 
creatures in whole of the world, especially, for obtaining prosperity and happiness of human being in some aspects of their life worldly and here after. ${ }^{3}$

So, it can be understood that the Enlightening Islamic Preaching of Muhammadiyah is not only attempting to transfer of Islamic values to the invited communities or peoples, but also to progress them in their own socio-cultural daily life. In other words, in this perspective, the activities of da'wah consist of at least two main components like twinsides of the same coin. First, verbal preaching (tabligh) of Islamic teachings to the invited communities or people (mad $\hat{u}$ ) in order to fervent and expand extensively the Islamic teachings according to Muhammadiyah`s understanding. Secondly, praxical action or actualization of Islamic values empirically in the context of plural communities, especially, the marjinal communities in order to emancipate and develop them with sustainable innovation. ${ }^{4}$

\section{Paradigm and Orientation of the Enlightening Islamic Preaching}

The Enlightening Islamic Preaching used the progressive Islam (Islam Berkemajuan) as a paradigm or basic worldview of it's thought and activities in da`wah movement. Idiologically, the progressive Islam paradigm based on some postulates that viewed Islam as more superior religion than the others (al-islâm ya 'lû walâ yu 'lù 'alaih), a moderat (wasathiah) religion, a dynamic (tafrah) religion, a blessed religion (dîn al-mardhiyyah), a civilization or culture (dîn al-hadârah wa altsaqâfah), relevant or compatible to human life any time and any place (shôlihun likulli zamânin wa makânin), and ect. ${ }^{5}$

Besides these postulates, the progressive Islam paradigm also pointed out some general Islamic teachings as the values of the movement of da wah, such as: enjoing the doing of what is good and forbidding the doing of what is wrong (alamr bi-al-ma'rûf wa al-nahy 'an al-munkar), transparency and wisdom (hikmah), beautiful preaching (mauizhah al-hasanah), liberating the people from the darkness towards the lightness (yukhriju al-nâs min al-zhulumât ilâa al-nûr), enjoying the doing of what is happiness according to divine teaching (tabsyir),

${ }^{3}$ PP Muhammadiyah, Pernyataan Pikiran....., p. 14

${ }^{4}$ Ibid., hlm. 4

${ }^{5}$ Din Syamsuddin, Pidato Iftitah Muktamar Muhammadiyah ke-47, Makassar, "Gerakan Pencerahan Menuju Indonesia Berkemajuan Refleksi, Proyeksi, dan Rekomendasi". n.y. : PP Muhammadiyah, 2015, p. 3. 
religious freedom (lâ ikrâha fî̀ al-dîn) and tolerance (tasâmuh), inclusiveness, fairness, and transformation. ${ }^{6}$

Essentially, these basic religio-theoretical frameworks of progressive Islam paradigm are appointed as the fundamental cornerstones of the Enlightening Islamic Preaching movement. It is built and constructed through integrating and combining the revealed divine doctrines with Islamic rational thought (ijtihâd), and achievements of modernization in the field of science and technology, in order to progress the culture and civilization of Islamic societies, especially, in the context of the contemporary Indonesian Muslim. In other words, it can be asserted that the Enlightening Islamic Preaching is based on Islamic teachings that consists of four dimensions dealing with beliefs (aqîdah), ritual worship ('ibâdah), ethics (akhlâq), and social interactions (mu'âmalah). Meanwhile, it's praxical activities have inclusively been adopting and usins a number of the progressive approaches, methods, and theories of sciences for liberating and developing Islamic societies in many aspects of their own life and humanities. $^{7}$

\section{The Strategies and Subject Matters of the Enlightening Islamic Preaching}

The Enlightening Islamic Preaching has untill now still been using three mainstrategies, such as: purification (tanzhîf), innovation (tajdîd), and transformation (tashlîh). The strategy of purification pays attention to the deviated beliefs and religious thought of ummah (commonly called as takhyul and khurafat), the heresy of the ritual worship/practices of ummah (called as bid ah) and the decadence of moralities of ummah. To the aspects of the deviated beliefs of ummah, the activities dawah are engaged to purify simultaneously the theological beliefs of Islamic societies with maintaining or refining a strict monotheism (tawhîd) and liberating their own beliefs from atheism, polytheism, syncretism, cultism, paganism, animism, dynamism, shamanism, mythologies, and so on. And, to the aspects of their religious thoughts, the strategy of purification emphasizes or advocates the independent reason/judgment (ijtihâd) in interpretation of the revealed texts (nush $\hat{u} s$ ) and oppose to the acceptance of the traditional interpretations propounded by ulama (taqlîd). However, to the

\footnotetext{
${ }^{6} \mathrm{PP}$ Muhammadiyah, Matan Keyakinan Muhammadiyah, dalam Manhaj Gerakan Muhammadiyah. (Yogyakarta: Suara Muhammadiyah dan Majelis Pendidikan Kader, 2009.)

${ }^{7}$ PP Muhammadiyah, Pernyataan Pikiran....., p. 6
} 
aspect of ritual worship practices, the strategy of purification attempts critically to explain the ummah the selective revealed teachings of the ritual worship systems according to Qor'an and the valid sunnah (al-sunnah al-maqbîlah), teachs or trains them practically with the correct worship and avoids them from the heretical worship (bid ah). Furthermore, to the aspect of moralities, the strategy of purification heightens ummah with the religious ethics, builds their character with Islamic values, and forbids them the doing of what is wrong, such as: indolence, suicide, addiction, permissiveness, freesex, tyrannism, terrorism, corruption, i.e.

Towards the worldly affairs, meanwhile, the Enlightening Islamic Preaching has still been using the strategy of sustainable innovation or Islamic modernization (tajdîd) through actualizing or optimalizing all of the potential creativities of ummah and humanities. In this sense, all of the best of classical Islamic societies traditions, the achivement of modern Muslim societies, local living wisdoms, and global civilization (especially science and technology) must be potitioned integrally interconnectively as "health ingredients" for developing the most progressive culture and civilization of Islamic world in the context of the contemporary era (al-muhâfhazhah 'alâ al-qadîm al-shâlih wa al-îjâd bi al-jadîd alashlah).

Therefore, the three mainstrategies of the Enlightening Islamic Preaching consist of not only purifying of the religious beliefs/thoughts, ritual worship practices and moralities of ummah, but also attempting for developing their worldly affairs or material prosperity according to Islamic teachings. In other words, the strategies of the Enlightening Islamic Preaching have been going to push the revitalization and transformation of Islamic teachings in order to creat the progressive ummah and hence civil society in the contemporary era. ${ }^{8}$

\section{Approaches and Methods of the Enlightening Islamic Preaching}

Muhammadiyah has integrally and interconnectively been using at least four approaches in the actions of da wah, such as: organizational approach, cultural approach, community development approach, and structural approach. The organizational approach is used to support both the program of The Communities Movement (named Gerakan Jama'ah ) and the program of The

8PP Muhammadiyah, Model Dakwah Pencerahan Berbasis Komunitas. (Yogyakarta dan Jakarta: PP Muhammadiayah, 2015.) p. 6 
Communities Preaching (called Dakwah Jama'ah). Both of the two were systematically established by Muhammadiyah on the $37^{\text {st }}$ Conference of Muhammadiyah in Yogyakarta 1968. ${ }^{9}$ Using the organizational approach, the movement of $d a$ 'wah is officially mobilized by the leaders of Muhammadiyah or the leaders of the communities. ${ }^{10}$ Consequently, beside of leadership abilities, the leaders must also have capabilities to become the religious preachers. Meanwhile, the leaders of the communities those who like to take apart in $d a^{\prime} w a h$ as the religious preachers can be appointed formally after participating on the program of preachers training held by Majelis Tabligh. Therefore, with using the organizational approaches, the da'wah movement can be managed systematically and regularly. ${ }^{11}$

In the otherwise, the Enlightening Islamic Preaching of Muhammadiyah has also been taking cultural approaches to do $d a{ }^{\prime} w a h^{\prime}$ s activities. ${ }^{12}$ The aims of this approach is to build the character of the invited members/societies with Islamic values considering on their potention and willingness as human being. Its means that the cultural approaches have been positioning and comprehending the invited members as people who have ideas, traditions, norms, system of activities, symbols, and tools that have been living in the their own cultural life. In this regard, of course, each of people may comprehend the things with special meanings.

Knowing the reality of the plurality of socio-cultures is most important. Especially, for the preachers those who would like to plan the effective and compatible strategies, approaches, methods, tools and the matters of da'wah according to the situation, condition, potention, and willingness of societies. Only with the best management will the activities of $d a^{\prime}$ wah be able to go smoothly, effectively, efficiently and succesfully. Its means that da'wah must be based on data or research of the living culture in society.

In this context, the reality of cultural-societies can be divided into three classifications. First, the culture of rural society that, in general, has been held and traditioned by farmers and small traders community in some countries or

\footnotetext{
${ }^{9}$ PP Muhammadiyah, Pernyataan Fikrian....., p. 3

${ }^{10} \mathrm{PP}$ Muhammadiyah, Pedoman Pokok Pembentukan Jama'ah, (Yogyakarta: Suara Muhammadiyah, 1977/2015), p. 10

${ }^{11}$ Haedar Nashir, "Pengantar Memahami Manhaj Gerakan Muhammadiyah" dalam PP Muhammadiyah, Manhaj Gerakan Muhammadiyah, Yogyakarta: Suara Muhammadiyah dan Majelis Pendidikan Kader, 2009, p. 5.

${ }^{12}$ Tanwir PP Muhammadiyah, 2002/2003.
} 
villages. In the context of Batak society, for example, the activity of da'wah could use the cultural identities of Batak, local wisdoms and arts. However, the ritual magic traditions of laying some food or flowers and reading magic formula (to spirits or souls, etc.) before starting of exhibition of margondang have to be changed with reciting Qoranic verses. In this regard, the exhibition must be not coloured or ornamented with the mystical dimensions or exploitation (ex. cultism of persons or things), but must be modified creatively with Islamic speechs, songs, poetries and stories in order to build the character of viewers and audiens with revealed values. Briefly, with using cultural approach, the da'wah movement is going to do Islamization of local socio-cultures critically, adaptively and creatively through actualizing the universal Islamic values as a gitf from God to all creatures (rahmatan lil âlamîn) in the human daily life. ${ }^{13}$ Second, the culture of urban society that is still going on formation around the people those who live in both around the centers and pheriperies of middle towns or big cities, such as: government officials, workers, teachers, celebrities, artists, journalists, middle class businessmen, i.e. Third, the culture of metropolitan/postindustrial society that was taken up by the communities or people those who have interacted or networked with global communities. They have firmly been enjoying the life style of the globalization era.

Using the cultural approach should not be meant as a legitimation or a justification for syncretism. The terminology of "cultural approach" is just used as a perspective in mapping the reality of the human culture to choose selectively which one of the models of $d a$ 'wah is the best or the most compatible to situation or condition of the society. Based on this meaning, it can be asserted that the cultural approaches of $d a a^{`} w a h$ of Muhammadiyah have substantially been aimed to respond and understand the plurality of social cultures. Thus, the meaningful ideas, customs, traditions, values, norms, system of activities, symbols, and anythings else that of the society have been integralized and purified with Islamic teachings according to Muhammadiyah's religious understanding. Therefore, actually, the characteristics of cultural approaches in Muhammadiyah`s perspective are dynamics, creative, and innovative. ${ }^{14}$

\footnotetext{
${ }^{13} \mathrm{P}$ Muhammadiyah, Dakwah Kultural Muhammadiyah. (Yogyakarta: Suara Muhammadiyah, 2004.) p. 26

14 Tanwir PP Muhammadiyah, 2002/2003.
} 
Historically, the cultural approaches in da'wah activities had been performed by Prophet Muhammad PBUH to the invented people (mad $u$ ). For example, although as a military internee Tsumamah ibn Utsal still had againt Islam arrogantly, however, Prophet Muhammad PBUH had sincerely positioned him as a leader of the tribe of Bani Hanifah and hence always given him some food and milk every day. Brieftly, at the end, Tsumamah had been interesting with Islam and inverting to become a Muslim. The cultural approaches also had used by K.H.Ahmad Dahlan through fulfilling the needs of societies, especially, in the aspect of education, healthy, social, and economy. His action had been responded positively and simpatically by a large number of societies. Finally, he had a great succesfull to widespread his da`wah through organization of Muhammadiyah.

Besides the cultural approaches, Muhammadiyah has simultaneously been using the socio-communal approaches in da'wah since its establishment through Dakwah Jamaah's model. It is very important to do mapping and categorizing the invented community/society (mad $\hat{u}$ ) according to their profession, stratification, hobby, ethnic identities, social stratification, owness, religion, spirits, residential location, hobbies, virtual media, and so on. And, in the contemporary era, merely, the communal approach is going to do dealing with much improvitation, such as: classifiying the invited community based on their needs and stratification, asserting some relevant strategies and methods relating with the their own situation and condition in contemporary social transformation.

In this perspective, communities are actually classified to, at least, three stratifications, such as: upper/high class, middle class, and lower/grass root class. Due to the upper/high class communities or the gated communities who are living in the luxury residence, for example, the activity of $d a^{\prime} w a h$ can be started with using the ecological approach. By ecological approach, the activity of $d a$ 'wah is starting with observing situation and condition or style of life of both the people those who are living around or outside of the luxury residence, such as: the owners, workers, servants, drivers, gardeners, security officers, i.e. and the interaction among them in social life, economy, politics, psychology, i.e. So, based on the results of this observation, problems, opportunities, challenges and barriers of Islamic preaching can be mapped and catagorized in order to do activities of da'wah succesfully. 
In this context, the activities of $d a$ 'wah can use some strategies or methods, such as:

1. Active learning of reciting of the Holy Qur'an for ladies, servants, gentlements, and so on.

2. Training of trainers or religious preachers,

3. Upgrading of religious capacity for the invented community

4. Optimalizing of the function of the mosques

5. Assistance and development social economy of outsiders of the luxury residence, i.e.

Related to these strategies or methods, the matters of $d a^{\prime} w a h$ are focused on the Islamic ritual aspects, sufism, Islamic symbols and philantrophy especially for the invented communities living in side of the luxury residence of the gated communities. It can bridge the gap or can strengthen the relationship between the have communities and the have not ones.

Then, to the middle class communities those who have high level autonomy, high social status but low spirituality, critical thought and behaviour, the activities of da'wah have to be packaged interestingly accordance with their own life style. Thus, the strategies and methods of $d a$ 'wah must be enriched with creative and innovative models in order to revitalize and enlighten their religious behaviour. Therefore, the activity of da'wah may be held on in the hotels, dooms, seminaries, study clubs, and so on with using interesting language, multimedia setting and publishing, i.e. to this segment of community, the motivation of working, strenghten of religious commitment and confirmation of way/goal of life can be taken as the matters of da'wah with Muhammadiyah's perspective in order to creat prosperity of their life, wordly and here after.

Meanwhile, to the marginal communities (mustadh afin), such as: workers, farmers, small traders, joblessmen/women, difablers, orphans, poors, ect., the activity of da'wah is done simultaneously with social practices and philantrophies. In this context, therefore, the matters of da`wah are focused on Islamic ethos and motivation of work, strenghten of Islamic characters, conselling around the religious affairs, education, assistance for socio-legal issues, cultures, solidarities, i.e. So, the preachers must can integralize some approaches verbally and actually with some introductional packages of knowledge, sciences, technologies, and arts. In this regard, the preachers must be upgrade simultaneously their capacity under the shelter of Islamic rules and procedures. 
They also must embede themselves in sciences, technologies, arts, and so on. Then, the aims of $d a$ 'wah is not only to emancipate, assist and advocate the rights or the interests of the marginal societies, but also to develop progressively their socio-cultural life. ${ }^{15}$

Besides socio-communal approach, moreover, the Enlightening Islamic Preaching is also going to start with using structural approach through both of nationality struggling and humanity (Jihad Kebangsaan dan Kemanusiaan) and constitutional struggling (Jihad Konstitusi). The former aims to build the character of generation. In this context, the activities of $d a^{2} w a h$ are going to cultivate to Muslim children, teenegers, students, ladies, gentlement, people, i.e. the humanities values and nationalism such as: integrity, honesty, confidence, bravely, courage, solidarity making, discipline, enterpreneurship, progressiveness, exellency, and ect.

Meanwhile, the latter aims to straight forward the vision (kiblat) of nation through judicial actions about laws, roles, and policies of goverment which were considered or predicted tends to inflict a financial loss and damage the public interest or state. This constitutional actions are still going simultenously on process and struggling as the attempts to check and balance the ruling goverment still keep running on the right track. For example, the actions are going to propose to Constitution of Justice to do the judicial review of law of gas and oil, law of water resources, law of mass organization, law of hospital, law of devisa system and traffic, law of investation, law of electricity, law of tax amnesty, ect.

Therefore, through structural approach, da`wah activities not only orient to uphold and maintain the goal of nation, but also to hold the mission of ummah as divine vigerence in the earth, especially, in the context of contemporary Indonesian Muslim. Then, in this context, Muhammadiyah actually committed to realize the national goals of Indonesia as a progressive nation, justice, prosperity, sovereignity, and dignity.

Furthermore, according to Muhammadiyah, Indonesia is state of concensus and that of testimony (Dâr al-'Ahd wa al-Syahâdah). ${ }^{16}$ As a state of concencus, Indonesia which was built with a lot of groups of socio-cultural

${ }^{15}$ Haedar Nashir, "Pengantar Memahami........., ," p. 5

${ }^{16} \mathrm{PP}$ Muhammadiyah, Muhammadiyah dan Isu-isu Strategis Keumatan, Kebangsaan, dan Kemanusiaan Universal, (n.y.: PP Muhammadiyah, 2015). PP Muhammadiyah, Negara Pancasila Sebagai Darul Ahdi Wa Syahadah. (N.P.: PP Muhammadiyah, 2015). 
communities was based on the four pillars, such as: Pancasila, UUD 1945, NKRI, and Bhineka Tunggal Ika (Unity in Diversity). Each of groups of Indonesian people, as nitizens, consequently, ought to base their idiologies, worldviews, loyalties, commitment and responsibilities on that of four pillars of nation. Meanwhile, as a state of testimony, Indonesia is potitioned as arena of competition in which all of plural societies can do competitively participating on fulfilling the program of developmentalism according to each of their ideologies, interests, strategies, dan methods (shibghat). So, in this regard, the activities of the Enlightening Islamic Preaching are struggling to actualize Islamic values in the context of both of national life and religious one (Jihad Keagamaan). In the context of national life, for example, the Enlightening Islamic Preaching tends to push creatively realization of the national independence goals and to ensurence it's going still on the principles of nation and state.

However, towards the phenomena of dinamization of globalization, the Enlightening Islamic Preaching put forward the humanization strategy with using several approaches interconnectively, such as: social approaches, cultural approaches, politics approaches, and religious approaches. In this context, the matters of $d a^{2} w a h$ focused on universal humanity values in order to widespread, cultivate, and revere it in the whole of the world in the contemporary era, such as: tolerance, plurality, morality, peace, i.e. through social approach, for example, the Enlightening Islamic Preaching considers using dialogical methods and cooperation among societies for making mutual understanding and bearing mutual respect of world's in order to realize the peace, security, harmony, and prosperity of societies globally. With cultural-religious approach, Muhammadiyah has still been holding or partisipating on interreligious or multicultural dialogue of civilizations, developing and fluorishing the model of relationship with the other of religious or non-religious organizations in the world in order to create a peaceful global order, and so on. For example, Muhammadiyah has been noted as a member of International Contact Group (ICG) and has been participating on peace for some bloody conflicts in the around of the world, such as Mindanao Muslim in Filipina, Thailand, Nigeria, Cosovo, Palestine, i.e. in the case of conflict that was faced by Muslim minorities in Philipine, Muhammadiyah has actively been participating as mediator bridging the gap between goverment of Philipines and Mooran Muslim societies (ILF). In Middle Africa and apart of Nigeria, Muhammadiyah had participated to 
make peace on the conflict between Muslim minorities and Christians. In Palestine and Kosovo, Muhammadiyah had actively participated on struggeling for independence of the two nations. Hence, beside of attempting to make peace the interreligious conflict of societies in North Thailand, Muhammadiyah has also been helping and facilitating the young Moslem generations of Thailand for study in several Muhammadiyah`s universities. ${ }^{17}$

\section{Infrastructures and Media of the Enlightening Islamic Preaching}

The Enlightening Islamic Preaching has commonly been engaging in establishment the socio-religious actions with some da'wah infrastructures. Mosques, orphans, schools, universities, medical clinics, hospitals, Wealth Houses of Muhammadiyah (Bait Tamwil Muhammadiyah/BTM), training centers, $\mathrm{TvMu}$, Radio $\mathrm{Mu}$, printing hause, libraries and autonomous organization of Muhammadiyah and other benevolent institutions as aparts of services that societies or communities can obtain. With using these infrastructures, The Enlinghtening Islamic Preaching struggles sistematically to widespread the scale of the preached people, including: children, adults, teenagers, students and postgraduate students, ladies, gentlements, people, i.e. In this regard, for example, training and education centers are dedicated to the common communities those who want to do workshop, training and studying on somethings according to their tendings, hobbies, professions and cultures. In the context of rural communities, for example, the activities $d a^{`} w a h$ can use the local or traditional arts and musics, such as: gondang, tortor, gamelan, wayang, batik, angklung, talempong, gambus, ect. ${ }^{18}$

Meanwhile, to the urban communities those who always need information, fashion, and entertainment, the preaching has not only been improved with using conventional tools, but also using mass media, especially, through magazines such as Suara Muhammadiyah, Berita Resmi Muhammadiyah, Majalah Suara Aisyiah, Majalah Al-Manar, Majalah Tabligh, Tuntunan Islam Majelis Tabligh, Majalah Matan), books (Manhaj Gerakan Muhammadiyah, Tarjih Muhammadiyah, Tafsir al-Tanwir Muhammadiyah, Tanya Jawab Agama 1st-6st editions, i.e), which have regularly been distributed to all of the branchs,

${ }^{17} \mathrm{PP}$ Muhammadiyah, Muhammadiyah dan Isu-isu Strategis Keumatan, Kebangsaan, dan Kemanusiaan Universal, (N.P.: PP Muhammadiyah, 2015).

${ }^{18}$ PP Muhammadiyah, Indonesia Berkemajuan Rekonstruksi Kehidupan Kebangsaan yang Bermakna, (N.P.: PP Muhammadiyah , 2015). 
territories and regions of Muhammadiyah, and also using electronic media, especially, Muhammadiyah television (TvMu) which relies regularly its programs consist of recitating of Qor'an, educating news, Islamic worship practices, Islamic speechs, Islamic talkshow, Islamic seminary, arts and entertainment, informations and ect. Thus, using all of these infrastructures and media, the daiwah activities have simultaneuosly been inviting Muslim communities to become members of Moslem society (ummah), commonly, or to become members of Muhammadiyah, especially.

\section{Relevances and Contributions}

The Enlightening Islamic Preaching is very urgent and still relevant to the context of Indonesian Muslim societies in order to face the challengges, to anticipate the barriers, and to take opportunities of the development in this contemporary era. Because, in the one side, Indonesian Muslim societies can not escape their life from the negative impacts of modernization and globalization such as: materialistic life style, capitalistic, hedonistic, permissivistic, liberalistic, syncretic, and secularistic. In the one side, a lot of social pathologies, like criminalities, conflicts of social-politics interest, violence, socio-legal unfairness, alineation, and cultural shock grow up glowly in the life of Muslim societies. In the other side, generally, Indonesian Muslim are still being backwardnessed or marginalized societies those who have a lack of opportunity in socio-cultural religious life. A lot of Indonesian Moslem societies, especially, still apply the clenic traditions, practices of shamanism, and hedonism life style which are ironically blew up or published intensively by mass media. In the context of the religious life of the internal Muslim societies, a lot of radical or liberal religious thoughts or sects rise and impact to make polarization and fragmentation of ummah. They intensively strike the stigmas to the each others, making negation, denying and deviating, ect. In the context of religious life of the external societies, many of religious missions that emerge with several strategies, approaches, methods and models potentially going to disturb the harmony of life of the interreligious societies, especially, in the grass roots communities which are becoming the target of exploitation, usually. ${ }^{19}$

All of that socio-cultural religious pathologies are going to impact to the spiritual dryness, the cultural lag and pshycal sickness of the life of Muslim

${ }^{19}$ PP Muhammadiyah, Ibid., 
society in this contemporary era. Based on these realities, the Enlightening Islamic Preaching has still been relevant to enlighten understandings and worldviews of Moslem societies, to emancipate and to improve Indonesian Muslim people from backwardness. In this regard, the Enlightening Islamic Preaching has also been important, if not necessity, to develop continously for making solutions to the problems of Muslim societies in the contemporary era. The Englightening Islamic Preaching has also been significant to motivate and assist them facing the challenges, barriers and opportunities of modernization and globalization. ${ }^{20}$

\section{CONCLUSION}

The concept of the Enlightening Islamic Preaching is a new model of da'wah of Muhammadiyah in the contemporary era. It has integrally been reconstructed and has interconnectively been reformulated by Muhammadiyah based on Islamic principles, Indonesian wisdoms, and the general values of humanities with some approaches and methods comprehensively. The Enlightening Islamic Preaching of Muhammadiyah could not only be understood as revitalization and reformulation the paradigm of da'wah of Muhammadiyah, but also could be appreciated as innovative and a progressive movement of its' da' wah in oder to make solutions to the complexity of problems which is faced by ummah and also to give them simultaneously guidance and to assist them on creating civil society in the context of contemporary Indonesia.

${ }^{20} \mathrm{PP}$ Muhammadiyah, Ibid., 


\section{REFERENCES}

Alqur'an Al-Karim

Muhammadiyah, PP. Indonesia Berkemajuan Rekonstruksi Kehidupan Kebangsaan yang Bermakna. N.P.: PP Muhammadiyah, 2015.

--------Pernyataan Pikiran Muhammadiyah Abad Kedua, Zhawâhir al-Afkâr alMuhammadiyah li al-Qarni al-Tsâni, Keputusan Muktamar Satu Abad Muhammadiyah (Muktamar ke-46 di Yogyakarta). T.T.: PP Muhammadiayah, 2015.

-------Laporan Pimpinan Pusat Muhammadiyah Periode 2010-2015. T.T. : PP Muhammadiyah, 2015.

--Model Dakwah Pencerahan Berbasis Komunitas. T.T.: PP Muhammadiayah, 2015.

--------Muhammadiyah dan Isu-isu Strategis Keumatan, Kebangsaan, dan Kemanusiaan Universal. T.T.: PP Muhammadiyah, 2015.

--------Negara Pancasila Sebagai Darul Ahdi Wa Syahadah. T.T.: PP Muhammadiyah, 2015.

--------Revitalisasi Visi dan Karakter Bangsa. T.T.: PP Muhammadiyah, 2015.

--------Matan Keyakinan Muhammadiyah, dalam Manhaj Gerakan Muhammadiyah. Yogyakarta: Suara Muhammadiyah dan Majelis Pendidikan Kader, 2009.

--------Dakwah Kultural Muhammadiyah. Yogyakarta: Suara Muhammadiyah, 2004.

--------Pedoman Pokok Pembentukan Jama'ah. Yogyakarta: Suara Muhammadiyah, 1977.

Din Syamsuddin, Pidato Iftitah Muktamar Muhammadiyah ke-47, Makassar, "Gerakan Pencerahan Menuju Indonesia Berkemajuan Refleksi, Proyeksi, dan Rekomendasi". T.T. : PP Muhammadiyah, 2015.

Haedar Nashir, "Dakwah Muhammadiyah dalam Perspektif Sosiologis", Makalah. Disampaikan pada Seminar Pra-Muktamar Satu Abad Muhammadiyah Tanggal 18-19 Desember 2009, di Kampus UMSU, Medan. 
FITRAH Jurnal Kajian Ilmu-ilmu Keislaman

Vol. 02 No. 2 Desember 2016

“Pengantar Memahami Manhaj Gerakan Muhammadiyah" dalam PP Muhammadiyah, Manhaj Gerakan Muhammadiyah, Yogyakarta: Suara Muhammadiyah dan Majelis Pendidikan Kader, 2009. 